\title{
The composition of the egg-parasitoid guild of the golden egg bug, Phyllomorpha laciniata (Heteroptera: Coreidae), in Spain
}

\author{
David Carrasco \& Gergely Várkonyi*
}

Carrasco, D. \& Várkonyi, G. 2012: The composition of the egg-parasitoid guild of the golden egg bug, Phyllomorpha laciniata (Heteroptera: Coreidae), in Spain. - Entomol. Fennica 23: 95-101.

The golden egg bug (Phyllomorpha laciniata (Villers)) is a phytophagous insect with an unusual reproductive system. Females use the bodies of conspecifics, both males and females, as oviposition substrates. In addition, a varying fraction of the eggs is laid on the food plant. Egg carrying on conspecifics increases offspring survival. Predators and, especially, hymenopteran parasitoids are the main cause of egg mortality. So far, only the wasp Gryon bolivari (Giard) (Hymenoptera: Scelionidae) has been reported as an egg parasitoid of $P$. laciniata in several Mediterranean populations. In this study, three new egg-parasitoid species are recorded from P. laciniata: the primary solitary parasitoids Gryon monspeliense (Picard) and Telenomus sp. (Hymenoptera: Scelionidae), and the facultative hyperparasitoid Ooencyrtus telenomicida (Vassiliev) (Hymenoptera: Encyrtidae). All of these parasitoids have been reared from host eggs being carried by conspecific bugs. We discuss the taxonomy and biology of the individual parasitoid species, as well as ecological and evolutionary aspects of the interactions in this host-parasitoid system.

D. Carrasco, Department of Plant Protection Biology, Division of Chemical Ecology, Swedish University of Agricultural Sciences, P.O. Box 102, SE-23053, Alnarp, Sweden; E-mail:dvd.crrsco@gmail.com

G. Várkonyi (*corresponding author), Finnish Environment Institute, Natural Environment Centre, Friendship Park Research Centre, Lentiirantie 342 B, FI88900 Kuhmo, Finland; E-mail: gergely.varkonyi@ymparisto.fi

Received 26 April 2011, accepted 12 August 2011

\section{Introduction}

The golden egg bug, Phyllomorpha laciniata (Villers, 1789) (Heteroptera: Coreidae) is a phytophagous insect distributed throughout the Mediterranean area (Moulet 1995). In Spanish populations, females mainly use their conspecifics, both males and other females, as oviposition substrates (Kaitala 1996, Kaitala \& Smith 2002, Reguera \& Gomendio 2002). Yet, some eggs can also be found on the food plant Paronychia ar- gentea Lam. (Caryophyllaceae). In the laboratory, females oviposit for over two months, laying clutches of 1-3 eggs every second day (Kaitala \& Miettinen 1997). Individuals are commonly found carrying eggs of different developmental stages in the field. Eggshell colouration covaries with the stage of larval development. Recently laid eggs are white, then they gradually turn yellow and eventually shiny golden. Nymphs leave the carrier directly after eclosion, whereas eggshells remain attached to the body of the bug. 
In the wild, eggs laid on plants suffer from higher mortality than those carried on bugs due to predators and, especially, parasitoid wasps (Kaitala 1996, Reguera \& Gomendio 2002, Gomendio et al. 2008). Thus far, only the scelionid wasp Gryon bolivari (Giard, 1895) has been reported as an egg parasitoid of the golden egg bug in different populations in Spain, France and Italy (Giard 1895, Mineo 1984, Kaitala 1996, Carrasco et al. 2007, Gomendio et al. 2008).

In this study, we report on a further three egg parasitoid species associated with the golden egg bug in different Spanish populations of P. lacini$a t a$, and discuss their taxonomy and biology as well as ecological and evolutionary aspects of the interactions in this host-parasitoid system.

\section{Materials and methods}

Adult $P$. laciniata individuals were collected from five locations within Spain during 2004 2008 (Table 1). One sampling site was situated in the Southwest near the locality of El Puerto de Santa María (Cádiz). The remaining sites were situated in the Northeast near the localities of Viladecans (Barcelona), El Prat de Llobregat (Barcelona), Llançà (Girona) and Portbou (Girona). The sites shared similar habitat characteristics. They were open areas surrounded by either maquis (shrub land) or beach dune habitat, with sandy gravel ground, low and patchy vegetation structure and abundant food plant $P$. argentea. Collection dates were selected according to the reproductive period of bugs in each place.

All parasitoid specimens were obtained from the eggs carried on P. laciniata individuals. Parasitized eggs are easily determined by their black colouration. We carefully removed parasitized eggs from the bugs using a small lab spoon. Parasitized eggs were stored inside small vials for incubation in laboratory conditions $\left(26 \pm 2{ }^{\circ} \mathrm{C}\right.$, L17:D7). After eclosion, parasitoids were preserved in $70 \%$ alcohol.

A batch of reared parasitoids obtained in 2005 was sent to Giovanni Mineo (Palermo, Italy) and Martti Koponen (Mikkeli, Finland) for identification of scelionid and encyrtid wasps, respectively. This material, together with the wasps reared dur- ing 2004-2008, was carefully re-examined by one of us (GV).

The identification literature employed in this study included (i) original descriptions of individual species: Giard (1895) for Gryon bolivari, Picard (1924) for G. monspeliense, Mineo \& Szabó (1978) for G. bosellii and Mineo (1979a) for Gryon laraichii; (ii) keys with detailed descriptions of species: Mineo (1981) to separate $G$. bolivari from $G$. bosellii, and Mineo (1979a) to distinguish between G. laraichii and G. monspeliense; (iii) revisions of Palaearctic species of Gryon Haliday (Kononova \& Petrov 2002, Kononova \& Kozlov 2008); (iv) a revision of the telenomine wasps (Hymenoptera: Scelionidae: Telenominae) of the USSR (Kozlov \& Kononova 1983); and (v) a key to the Palaearctic species of Ooencyrtus Ashmead (Trjapitzin 1978).

Morphological terminology follows Mineo (1980, 1981) and Masner (1980, 1983).

\section{Parasitoid species pool}

Insect rearing conducted in 2004-2008 yielded altogether four egg parasitoid species of $P$. laciniata. Next we provide sampling data for each species and discuss their taxonomy and biology.

\subsection{Gryon bolivari (Giard, 1895) (Hymenoptera: Scelionidae: Scelioninae)}

Material examined:

- 1q El Puerto 10.V.2005, 2 ㅇ Cap de Ras 5.VI.2005 (det. G. Mineo)

- $10 \hat{\jmath}+6$ ㅇ El Puerto 1.-10.V.2004, 17ðे+ $11+$ El Puerto 2.-15.V.2005, $2 \hat{\jmath}+4 q$ El Puerto 10.V.2005, 1ठ Cap de Ras 1.5.VI.2005, $1 \hat{\jmath}+1$ ㅇ Cap de Ras 5.VI.2005, 19 Remolar 23.V.2007, $4 \hat{\varnothing}+3$ + Remolar 2008, 8 $\widehat{\jmath}+10$ ㅇ Carrabiners 2008 (det. GV) - $1 ð+49$ Coll del Frare 26.V.2006 (det. DC)

We found a greater variation in this species than reported earlier (cf. Mineo 1981, Kononova \& Kozlov 2008), in particular in the length ratio of postmarginal $(\mathrm{pm})$ and stigmal $(\mathrm{st})$ veins as well as in the length of the longitudinal striae on metasomal tergite 2 (T2). In fact, the range of 
Table 1. Localities, sampling years of Phyllomorpha laciniata individuals, and parasitoid species reared in each sampling site.

\begin{tabular}{|c|c|c|c|c|}
\hline Sampling site & Coordinates & Locality & Years & Parasitoid species \\
\hline El Puerto & $36^{\circ} 36^{\prime} \mathrm{N}, 6^{\circ} 15^{\prime} \mathrm{W}$ & El Puerto de Santa María & 2004,2005 & $\begin{array}{l}\text { G. bolivari } \\
\text { O. telenomicida }\end{array}$ \\
\hline Remolar & $41^{\circ} 16^{\prime} \mathrm{N}, 2^{\circ} 03^{\prime} \mathrm{E}$ & Viladecans & 2007,2008 & $\begin{array}{l}\text { G. bolivari } \\
\text { G. monspeliense }\end{array}$ \\
\hline Carrabiners & $41^{\circ} 17^{\prime} \mathrm{N}, 2^{\circ} 07^{\prime} \mathrm{E}$ & El Prat de Llobregat & 2007,2008 & $\begin{array}{l}\text { G. bolivari } \\
\text { G. monspeliense } \\
\text { O. telenomicida }\end{array}$ \\
\hline Cap de Ras & $42^{\circ} 23^{\prime} \mathrm{N}, 3^{\circ} 09^{\prime} \mathrm{E}$ & Llançà & $2005,2006,2007,2008$ & $\begin{array}{l}\text { G. bolivari } \\
\text { G. monspeliense } \\
\text { O. telenomicida }\end{array}$ \\
\hline Coll del Frare & $42^{\circ} 25^{\prime} \mathrm{N}, 3^{\circ} 09^{\prime} \mathrm{E}$ & Portbou & 2006 & $\begin{array}{l}\text { G. bolivari } \\
\text { Telenomus sp. }\end{array}$ \\
\hline
\end{tabular}

variation in our material partially overlapped with that found in G. bosellii Mineo and Szabó, 1978 (see Mineo 1981, Kononova \& Kozlov 2008). However, all our individuals shared the character of possessing short rows of minute teeth on the mesoscutum along the lines of notauli (referred to as "abbreviate sulci" in Mineo (1981); see his Fig. II on p. 121 (ibid.) and Fig. 4 on p. 237 in Mineo (1979b)), which is a unique character of G. bolivari (Mineo 1979b, 1981).

Based on (i) the possession of this unique character; (ii) the fact that variability in the above mentioned characters occurred as continua rather than distinct character states; and (iii) that host eggs producing morphologically variable $G$. bolivari individuals were sampled from the same carrier bug specimens on the same days, we concluded that it is not justified to divide our reared material into two species, i.e. G. bolivari and $G$. bosellii.

In the remarks of a description of $G$. bosellii, Mineo (1981, p. 126) provides the following character states to separate these closely related species: "G. bosellii is the only species which has in the female the postmarginalis as long as stigmalis. This character and the coarse striae running only in the middle of T2 for about $1 / 4$ of its length easily distinguish this species from $G$. bolivari. Further it appears rather than constantly black in the body colour." We found the following pattern in our material: specimens with dark mesosoma and metasoma were on average more coarsely sculptured, and the longitudinal striae on $\mathrm{T} 2$ were longer, than in light-coloured specimens. The colour of the mesosoma and metasoma varied from almost uniformly red-brown to fully black. A large proportion of specimens had a dark mesosoma but the colour of the metasoma ranged from red-brown to black. Females had on average a slightly shorter $p m$ than st, but in a few specimens $\mathrm{pm}$ was equal to or even slightly longer than $s t$. In males, $p m$ was usually somewhat longer than $s t$, but we have also seen a single specimen with $p m<s t$. Owing to the considerable variation of these character states found in G. bosellii, the most useful character to reliably separate this species from $G$. bolivari seems to be the absence of the short rows of minute teeth on the mesoscutum along the lines of notauli (see above).

The known hosts of $G$. bolivari include Phyllomorpha laciniata (e.g. Giard 1895, Mineo 1979b, Mineo 1984, Kaitala 1996, Carrasco et al. 2007), Coreus marginatus (Linnaeus, 1758) (Heteroptera: Coreidae) and an unidentified species of Rhopalidae (Heteroptera) (Mineo 1979b). Moreover, Mineo (1979b) postulated that, since $G$. bolivari is also distributed in areas where its known hosts fail to occur, G. bolivari would parasitize other coreid species. Gryon bolivari was fairly abundant and strongly associated with $P$. laciniata in all our study sites (Table 1). However, being an idiobiont parasitoid of heteropteran eggs, G. bolivari may also attack alternative hosts even in the presence of $P$. laciniata. 
3.2. Gryon monspeliense (Picard, 1924) (Hymenoptera: Scelionidae: Scelioninae)

Material examined:

- 1 ㅇ Cap de Ras 1.-5.VI.2005 (det. G. Mineo as G. laraichii)

- 1q Cap de Ras 11.V.2006, $1 q$ Remolar

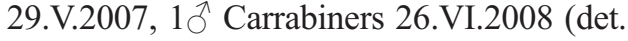
GV)

Gryon laraichii Mineo, 1979 was originally described in a key couplet (Mineo 1979a) along with $G$. monspeliense. In the same year, Mineo (1979b) gave a description of this new species, in which he addresses the problem of failing to find strong morphological differences to separate $G$. laraichii from $G$. monspeliense. In their recent monograph of Palaearctic Scelionidae, Kononova and Kozlov (2008) considered the name $G$. laraichii Mineo to be a junior synonym of $G$. monspeliense (Picard). Hence, we refer to this species as $G$. monspeliense.

The known host range of $G$. monspeliense includes Aelia rostrata Boheman, 1852, A. germari Küster, 1852 (Pentatomidae), Eurygaster integriceps Puton, 1881 (Scutelleridae), Gonocerus acuteangulatus (Goeze, 1778) (Coreidae) (Mineo 1979a,b, Kononova \& Kozlov 2008) and $P$. laciniata (Coreidae) (new host record added here). Gryon monspeliense seems to be a fairly rare but constant member of the egg-parasitoid guild of $P$. laciniata in northeastern Spanish study sites (Table 1). Phyllomorpha laciniata is probably not the main host of this species.

\subsection{Telenomus (Telenomus) sp. (Hymenoptera: Scelionidae: Telenominae)}

Material examined:

- $1 ð+1 q$ Coll del Frare 26.V.2006

We used the revision of the subfamily Telenominae by Kozlov and Kononova (1983) in our attempt to identify this species. Although it is evident that it belongs to the species-rich subgenus Telenomus of the genus Telenomus Haliday, 1833 , this species did not fit the description of any species in the revision used. Hence, for the time being, we refer to it as an unidentified species in the genus Telenomus. In any case, and in spite of the vagueness of our identification, we note that this is the first record of this subfamily as parasitoids of $P$. laciniata.

\subsection{Ooencyrtus telenomicida (Vassiliev, 1904) (Hymenoptera: Encyrtidae)}

Material examined:

- $1 \hat{\jmath}+1$ q without label data (det. M. Koponen; the remaining material: det. GV)

- $5 \hat{\jmath}+5$ ㅇ El Puerto 1.-10.V.2004

- $1 \widehat{\jmath}+1$ 으 El Puerto 20.V.2004

- 1 ઈ̂ El Puerto 2.-15.V.2005

$-1 \lesssim+1 q$ hatched from a single host egg, Cap de Ras 28.V.2005

$-1 \hat{\jmath}+3 \bigcirc$ (hatched) +1 pharate $q$ inside host egg, Cap de Ras 11.V.2006

- 7 ㅇ + 1 pupa Cap de Ras 25.V.2007

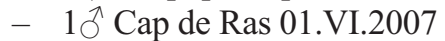

- 1 ô Cap de Ras 08.VI.2007

- $2 \hat{\jmath}+2$ + Cap de Ras 15.VI.2008

$-1 q+2 \hat{\jmath}$ (hatched) $+1 \delta$ inside host egg +1 pharate adult inside host egg, Carrabiners 2008

$-4 \hat{\bigcirc}+16$, (specimens without label data) 2008

This species has a vast distribution area from Germany in the north to Syria and Iran in the south, and from Spain, Portugal and Morocco in the west to eastern China in the east (Noyes 2001, Zhang et al. 2005). Ooencyrtus telenomicida has a very wide host range composed of many species in mainly heteropteran (Coreidae: 6 spp., Pentatomidae: 18 spp., Pyrrhocoridae: 1 sp., Reduviidae: 1 sp., Scutelleridae: 3 spp.) and lepidopteran (1 sp. in each: Lasiocampidae, Lymantriidae, Notodontidae, Papilionidae and Sphingidae) families (Noyes 2010). Phyllomorpha laciniata is a new coreid host for this species. There are also a few records of primary egg-parasitoid hosts of $O$. telenomicida in the hymenopteran genera Trissolcus Ashmead and Telenomus Haliday (Scelionidae: Telenominae: Telenomini) (Noyes 2001). 


\section{Interaction between parasitoids}

According to the literature (see Noyes 2001 and references therein), O. telenomicida is a primary egg parasitoid or a (facultative) hyperparasitoid. This species was abundant in both the southern and the northeastern study areas and it frequently coexisted with $G$. bolivari (Table 1). As we have no direct observations of parasitism of $G$. bolivari by $O$. telenomicida, the nature of their interaction might be competition over eggs of $P$. laciniata, hyperparasitism, or both.

Unlike the scelionid parasitoids of $P$. laciniata eggs, which developed as solitary parasitoids, eggs attacked by $O$. telenomicida sometimes produced two adult parasitoids (see section 3.4.) that were smaller than their solitary conspecifics. Moreover, all P. laciniata eggs hosting $O$. telenomicida contained numerous undeveloped eggs. A potential explanation for this phenomenon is superparasitism by (different female individuals of) O. telenomicida. An alternative mechanism, i.e. oviposition of several eggs by a single female parasitoid, is known from several koinobiont larval endoparasitoids (see Godfray 1994 for a review). Such behaviour might be favoured by selection as it may exhaust the cellular immune response of the host. However, in idiobiont parasitoids such as $O$. telenomicida, laying several eggs in a single host egg probably would not be similarly beneficial. Nonetheless, at present we have no means to validate either of the two alternative hypotheses.

Gregarious development is widely known to occur in Ooencyrtus species. For instance, $O$. nezarae Ishii, 1928 has been reported to parasitize four species of phytophagous bugs in Japan and to develop as a gregarious parasitoid in one of them (Mizutani et al. 1996). This parasitoid is usually solitary in a small host but gregarious in a large host (Takasu \& Hirose 1991), suggesting that the size of progeny depends on both host size and the outcome of competition following superparasitism. Superparasitism is in fact very common in $O$. nezarae (e.g. Takasu \& Hirose 1991). In a similar host-parasitoid system found in Venezuela (Conde \& Rabinovich 1979), consisting of eggs of the reduviid bug Rhodnius prolixus Stål, 1859 and their parasitoids Telenomus costalimai Ortiz \& Alvarez, 1959 and
Ooencyrtus venatorius De Santis \& Vidal Sarmiento,1976, O. venatorius was a generally more successful competitor than T. costalimai after nearly simultaneous oviposition by the two parasitoid species. Another example of a hostmultiparasitoid community engaging Ooencyrtus was studied in California (e.g. Amarasekare 2003). In that system, Trissolcus murgantiae Ashmead, 1893 and Ooencyrtus johnstonii (Howard, 1898) both attack the eggs of the pentatomid harlequin bug Murgantia histrionica (Hahn, 1834). Ooencyrtus johnstonii is a gregarious and superparasitic species competing with the solitary T. murgantiae for host eggs, and the latter parasitoid is superior in this exploitative competition. It has also been shown that interaction between these coexisting parasitoid species dampens host population fluctuations (Amarasekare 2003).

\section{Interaction between $P$. laciniata and its egg parasitoids}

It is important to underline the evolutionary-ecological significance of our new rearing records from the viewpoints of both the host and the parasitoid species. Parasitoids act as selective pressure on their hosts. As a result, new adaptations may arise in the host species in order to minimize the risk of parasitism. It has been suggested that oviposition on conspecifics in $P$. laciniata may represent a strategy to reduce predation and parasitism of the eggs (Kaitala 1996, Reguera \& Gomendio 2002, Carrasco et al. 2007, Gomendio et al. 2008, Carrasco \& Kaitala 2009, Carrasco \& Kaitala 2010). The new parasitoid records reported in this study increase markedly the diversity of parasitoid species found to be associated with $P$. laciniata eggs. These results give further support to the hypothesis that egg parasitoids play an important role in the oviposition strategy of $P$. laciniata females, and may help to explain the evolution of such unusual behaviour. Nevertheless, additional investigations should be conducted to test this hypothesis. For instance, there is a need to assess the incidence of individual parasitoid species in P. laciniata eggs in various populations. It may be interesting to study further (see Gomendio et al. 2008) the relationship be- 
tween the incidence of egg-parasitism and the oviposition strategy of $P$. laciniata among populations, especially those in which female egg-laying behaviour differs from ovipositing primarily on conspecifics (e.g. Kaitala 1996, Reguera \& Gomendio 2002, D. Carrasco, S. Kivelä \& A. Kaitala unpubl.) by ovipositing mostly on plants and other substrates (e.g. Mineo 1984, D. Carrasco, L. Härkönen \& A. Kaitala unpubl.).

A previous study shows that $P$. laciniata individuals counteract most of the attempts of G. bolivari to approach the eggs they carry (Carrasco \& Kaitala 2010). The authors suggest that the mere fact of egg carrying and the behavioural responses bugs display against parasitoids may considerably decrease the rate of successful egg parasitization and increase the length of the parasitoid's host location process. Thus, as the time cost in parasitizing the eggs carried by bugs may be higher compared to eggs deposited on plants (or eggs of other species), the benefit to the idiobiont parasitoid species reported in this study (particularly G. bolivari, G. monspeliense and $O$. telenomicida) that parasitize eggs carried on $P$. laciniata remains unclear. Further studies on this host-multiparasitoid system should investigate: (i) the host location mechanism of each parasitoid species; (ii) the interaction between coexisting parasitoid species; and (iii) whether these parasitoids gain some fitness benefit, such as reduced predation or reduced superparasitism and/or hyperparasitism, by exploiting the egg-carrying and defensive behaviour of adult $P$. laciniata.

Acknowledgements. We are grateful to Martti Koponen and Giovanni Mineo for identifying some of the parasitoid material. We wish to thank Gavin Broad and an anonymous referee for their valuable comments. Special thanks to "Consortium of the Natural Areas of Delta del Llobregat" (http://www.deltallobregat.cat) for permission to work in the study areas of Remolar and Carrabiners. We also wish to thank Q. Daura, A. Torné and S. Varga for their help during field work. Finnish Cultural Foundation, Oskar Öflunds Stiftelse, CIMO Fellowships and Alfred Kordelin Foundation (grants to DC) supported this study.

\section{References}

Amarasekare, P. 2003: Diversity-stability relationships in multitrophic systems: an empirical exploration. Journal of Animal Ecology 72: 713-724.
Carrasco, D., Borg, Å. A. \& Kaitala, A. 2007: Egg-laying in relation to egg substrate in Gryon bolivari, an egg parasitoid of the golden egg bug (Phyllomorpha laciniata). - Journal of Insect Behavior 20: 307-313.

Carrasco, D. \& Kaitala, A. 2009: Egg-laying tactic in Phyllomorpha laciniata in the presence of parasitoids. Entomologia Experimentalis et Applicata 131: 300 307.

Carrasco, D. \& Kaitala, A. 2010: Active protection of unrelated offspring against parasitoids. A byproduct of self defense? - Behavioral Ecology and Sociobiology 64: 1291-1298.

Conde, J. E. \& Rabinovich, J. E. 1979: Larval competition between Telenomus costalimai (Hymenoptera: Scelionidae) and Ooencyrtus trinidadensis venatorius (Hymenoptera: Encyrtidae) after simultaneous oviposition in Rhodnius prolixus eggs (Hemiptera: Reduviidae). - Journal of Medical Entomology 16: 428-431.

Giard, A. 1895: Sur quelques especes nouvelles d'Hyménoptères parasites. - Bulletin de la Société Entomologique de France (1895): 74-78.

Godfray, H. C. J. 1994: Parasitoids. Behavioral and evolutionary ecology. - Princeton University Press, Princeton. $473 \mathrm{pp}$.

Gomendio, M., García-González, F., Reguera, P. \& Rivero, A. 2008: Male egg carrying in Phyllomorpha laciniata is favoured by natural not sexual selection. Animal Behaviour 75: 763-770.

Kaitala, A. 1996: Oviposition on the back of conspecifics: An unusual reproductive tactic in a coreid bug. - Oikos 77: 381-389.

Kaitala, A. \& Miettinen, M. 1997: Female egg dumping and the effect of sex ratio on male egg carrying in a coreid bug. - Behavioral Ecology 8: 429-432.

Kaitala, A. \& Smith, R. L. 2002: Do golden egg bugs (Phyllomorpha laciniata: Heteroptera, Coreidae) require conspecifics for oviposition? - Journal of Insect Behavior 15: 171-180.

Kononova, S. V. \& Petrov, S. 2002: (Review of the genera Gryon and Exon (Hymenoptera, Scelionidae) of the Palaearctic. 2. A key for identification of Gryon species and a review of the genus Exon). - Zoologichesky Zhurnal 81: 53-59. [In Russian.]

Kononova, S.V. \& Kozlov, M. A. 2008: (Scelionids of the Palearctic (Hymenoptera, Scelionidae). Subfamily Scelioninae). - Tovarishchestvo Nauchnykh Izdanij KMK, St. Petersburg-Moskow. 489 pp. [In Russian.]

Kozlov, M. A. \& Kononova, S. V. 1983: (The Telenominae of the fauna of the USSR). — Nauka, Leningrad. 344 pp. [In Russian.]

Masner, L. 1980: Key to the genera of Scelionidae of the Holarctic region, with descriptions of new genera and species (Hymenoptera: Proctotrupoidea). - Memoirs of the Entomological Society of Canada No. 113: 154.

Masner, L. 1983: A revision of Gryon Haliday in North America (Hymenoptera: Proctotrupoidea: Scelionidae). — The Canadian Entomologist 115: 123-174.

Mineo, G. 1979a: Studi sugli Scelionidi (Hymenoptera, Proctotrupoidea): VII. Sulle specie Paleartiche del ge- 
nere Gryon Haliday parassite di Aelia ed Eurygaster spp. (Heteroptera, Pentatomidae). - Il Naturalista siciliano Ser. IV 3(3-4): 91-97. [In Italian.]

Mineo, G. 1979b: Studies on the Scelionidae (Hym. Proctotrupoidea) IX. Material for a revision of the genus Gryon Hal., with description of 4 new species ( $G$. austrafricanum, G. eremiogryon, G. laraichii, G. nicolai) and notes on other Scelionids. - Bollettino del Laboratorio Entomologia Agraria "Filippo Silvestri" di Portici 36: 234-265.

Mineo, G. 1980: Studies on the Scelionidae (Hym. Proctotrupoidea) XI. A revision of the Palearctic species of Gryon Haliday: the insulare and pubescens groups. Bollettino dell'Istituto di Entomologia agraria e dell'Osservatorio di Fitopatologia di Palermo 10: 213-226.

Mineo, G. 1981: Studies on the Scelionidae (Hym. Proctotrupoidea) XIII. A revision of the Palaearctic species of Gryon Haliday: The muscaeformis-group. — Redia 64: $117-147$.

Mineo, G. 1984: Notizie biologiche su Phyllomorpha laciniata (Vill.) (Rhynchota, Het., Coreidae). — Phytophaga 2: 117-132. [In Italian.]

Mineo, G. \& Szabó, J. B. 1978: Description of two new Palearctic species of Gryon Haliday (Hymenoptera: Scelionidae). - Bollettino dell'Istituto di Entomologia agraria e dell'Osservatorio di Fitopatologia di Palermo 10: 113-120.

Mizutani, N., Hirose, Y., Higuchi, H. \& Wada, T. 1996: Seasonal abundance of Ooencyrtus nezarae Ishii (Hymenoptera: Encyrtidae), an egg parasitoid of phytophagous bugs, in summer soybean fields. - Japanese Journal of Applied Entomology and Zoology 40: 199_ 204.
Moulet, P. 1995: Hémiptères Coreoidea (Coreidae, Rhopalidae, Alydidae), Pyrrhocoridae, Stenocephalidae Euro-Méditerranéens. Faune de France. Vol. 8. — Fédération Française des Sociétés de Sciences Naturelles, Paris. 336 pp.

Noyes, J. 2001: Interactive catalogue of world Chalcidoidea 2001. — CD-ROM. Taxapad and The Natural History Museum.

Noyes, J. S. 2010: Universal Chalcidoidea Database. [www document] URL http://www.nhm.ac.uk/entomology/chalcidoids/index.html. (Site visited in April, 2011.)

Picard, F. 1924: Description d'un nouveau Proctotrypide du genre Hadronotus [Hym.]. - Bulletin de la Société Entomologique de France (1924): 107-109.

Reguera, P. \& Gomendio, M. 2002: Flexible oviposition behavior in the golden egg bug (Phyllomorpha laciniata) and its implications for offspring survival. - Behavioral Ecology 13: 70-74.

Takasu, K. \& Hirose, Y. 1991: The parasitoid Ooencyrtus nezarae (Hymenoptera, Encyrtidae) prefers hosts parasitized by conspecifics over unparasitized hosts. Oecologia 87: 319-323.

Trjapitzin, V. A. 1978: Encyrtidae. — In: Trjapitzin V. A. (ed.), (Guide for the identification of the insects of European parts of the USSR.Vol. III Hymenoptera. Part 2). pp. 236-328. Nauka, Leningrad. 759 pp. [In Russian.]

Zhang, Y.-Z., Li, W. \& Huang, D.-W. 2005: A taxonomic study of Chinese species of Ooencyrtus (Insecta: Hymenoptera: Encyrtidae). - Zoological Studies 44: 347-360. 